\title{
PENGARUH FAKTOR PRODUKSI TERHADAP PRODUKTIVITAS BUNCIS PERANCIS: STUDI KASUS DI KELOMPOK TANI TRANGGULASI SEMARANG
}

\section{Effect of production factor on productivity of french bean: Case study at farmer group of Tranggulasi Semarang}

\author{
Wiwi Sepriani $^{1 *}$ dan Liska Simamora ${ }^{2}$ \\ ${ }^{1}$ Universitas Kristen Satya Wacana (UKSW), J1. Menur 36, Salatiga, Jawa Tengah \\ ${ }^{2}$ Universitas Kristen Satya Wacana (UKSW), Jl. Osamaliki Gg. Andong IX 28, \\ Salatiga, Jawa Tengah
}

Alamat Korespondensi: wiwisepriani1009@gmail.com

\begin{abstract}
ABSTRAK
Buncis Perancis merupakan salah satu komoditas unggulan yang dibudidayakan Kelompok Tani Tranggulasi Desa Batur, Kecamatan Getasan Kabupaten Semarang. Buncis perancis memiliki manfaat bagi kesehatan, sehingga permintaan yang tinggi di dalam negeri bahkan sudah menembus pasar ekspor. Permintaan pasar terhadap komoditas buncis perancis sebanyak 1,5-3 ton per hari, akan tetapi volume produksi buncis perancis di kelompok tani Tranggulasi hanya 1,5-3 ton per minggu. Namun, permintaan yang tinggi tersebut tidak mampu dipenuhi oleh petani yang tergabung dalam kelompok tani Tranggulasi karena jumlah produksi lebih sedikit dibandingkan permintaan. Penelitian ini bertujuan untuk menganalisis faktor-faktor produksi (luas lahan, benih, pupuk organik, tenaga kerja dan pestisida organik) yang mempengaruhi produktivitas komoditas buncis perancis dan mengetahui faktor produksi yang paling berpengaruh dalam peningkatan produktivitas buncis perancis di kelompok tani Tranggulasi, Desa Batur, Kecamatan Getasan, Kabupaten Semarang. Riset ini dilakukan pada bulan Agustus 2020. Sampel yang digunakan adalah anggota kelompok tani Tranggulasi sebanyak 30 orang yang ditetapkan secara purposive. Petani responden yang bergabung dengan kelompok tani Tranggulasi melakukan usahataninya dengan sistem pertanian organik. Data diperoleh dengan melaksanakan wawancara melalui daftar pertanyaan yang tertulis di dalam kuesioner. Analisis data dilakukan dengan pemodelan fungsi produksi regresi berganda dengan bantuan program SPSS 16. Hasil penelitian ini menunjukan bahwa faktor produksi luas lahan $\left(\mathrm{X}_{1}\right)$, benih $\left(\mathrm{X}_{2}\right)$, pupuk organik $\left(\mathrm{X}_{3}\right)$, tenaga kerja $\left(\mathrm{X}_{4}\right)$ dan pestisida organik $\left(\mathrm{X}_{5}\right)$ secara bersama-sama (simultan) mempengaruhi produktivitas buncis perancis di kelompok tani Tranggulasi. Namun secara parsial faktor produksi pupuk organik $\left(\mathrm{X}_{3}\right)$ berpengaruh positif dan nyata dalam peningkatan produktivitas buncis perancis di kelompok tani Tranggulasi.
\end{abstract}

Kata kunci: buncis perancis, faktor produksi, produktivitas

\begin{abstract}
French bean is one of the premier commodities of Tranggulasi farmer group at Batur Village, Getasan Sub-district, Semarang Regency, because having health benefits and the high demand in the country has even penetrated the export market. The market demand for as much commodity french bean 1,5-3 tons per day, but the volume of the French bean production of Tranggulasi farmer group just 1,5-3 tons per week. However, this high demand was inadequate for farmers belonging to the Tranggulasi farmer because their production is less than the demand. This study aims to analyze factors of production (land area, seeds, organic fertilizers, labor and organ ic pesticides) that influence the productivity of French beans, further, to find out the production factors that significantly influence the increasing the productivity of French beans. This research was conducted in August 2020. The sample of this study is the member of the Tranggulasi farmer group as many as 30 people by purposive method. The farmers respondents in the farm Tranggulasi group undertook their farmers efforts through the organic farming system. Data obtained by conducting interviews through a questionnarie's list of question. Data analysis is done by modeling the production function based in multiple regression with the help of SPSS 16. Results of this study indicate that production factors of land area $\left(X_{1}\right)$, seeds $\left(X_{2}\right)$, organic fertilizers $\left(X_{3}\right)$, labor $\left(X_{4}\right)$ and organic pesticides $\left(X_{5}\right)$ simultaneously influence the productivity of French beans of Tranggulasi farmer group. However, the organic fertilizer production factor $\left(X_{3}\right)$ had partially a positive and significant effect on the increasing of French beans productivity of Tranggulasi farmer group.
\end{abstract}

Keywords: French beans, productivity, production factors 


\section{PENDAHULUAN}

Sayuran merupakan salah satu tanaman hortikultura yang memiliki peluang pasar yang besar baik di pasar lokal maupun pasar ekspor. Komoditas sayuran berkontribusi untuk meningkatkan pembangunan nasional. Sayuran memiliki nilai ekonomi yang tinggi sehingga produktivitasnya harus efisien untuk menghasilkan produk yang berkualitas. Seiring dengan perkembangan penduduk, kebutuhan sayuran di Indonesia mengalami peningkatan setiap tahunnya akan tetapi, pemenuhan kebutuhan sayuran belum terpenuhi. Hal ini terjadi karena rendahnya produktivitas sayuran yang dibudidayakan oleh petani (Lama \& Kune, 2016). Produktivitas merupakan rasio antara besaran jumlah output terhadap besaran input yang digunakan sehingga produktivitas (Martono, 2019).

Desa Batur merupakan pusat produksi sayur organik yang berada di Kecamatan Getasan dengan mayoritas pekerjaan utama masyarakatnya sebagai petani yang umumnya membudidayakan tanaman hortikultura. Desa Batur membentuk kelompok tani sebagai wadah untuk mengembangkan usaha tani. Salah satunya adalah kelompok tani Tranggulasi. Kelompok tani Tranggulasi menjadi lembaga pelatihan pertanian yang didirikan dan dikelola oleh petani di Desa Batur secara swadaya baik perorangan maupun berkelompok. Kelompok tani ini diharapkan dapat berperan secara langsung dalam pembangunan pertanian di Desa Batur melalui pengembangan sumber daya manusia.

Jumlah anggota kelompok tani Tranggulasi sebanyak 32 orang, dengan membudidayakan berbagai komoditas sayuran dengan sistem pertanian organik. Terdapat 49 komoditas sayuran yang dibudidayakan oleh kelompok tani Tranggulasi diantaranya buncis perancis, brokoli, bayam jepang, sawi putih, kol, wortel, selada, bawang daun, kubis dan lain-lain. Komoditas buncis perancis adalah salah satu komoditas unggulan yang sudah menembus pasar ekspor serta memiliki permintaan yang tinggi. Buncis perancis ini sangat produktif dengan berbuah lebat, memiliki polong $15 \mathrm{~cm}$ dengan warna hijau terang, disamping itu buncis perancis termasuk tanaman sayuran yang tidak ditemu tipe simpang sehingga dapat dikatakan varietas buncis perancis memiliki keseragaman (Eka \& Gilang, 2013).

Luas lahan yang diusahakan oleh kelompok tani Tranggulasi untuk budidaya komoditas buncis perancis seluas 4,8 ha. Kapasitas lahan yang diusahakan setiap petani untuk menanam buncis perancis hanya seluas $0,1-0,3$ ha. Lahan merupakan salah satu yang menunjang produksi kelompok tani dalam melakukan usahatani. Faktor produksi adalah benih, pupuk 
kandang, pestisida, tenaga kerja dan luas lahan berpengaruh nyata terhadap jumlah produksi sayuran (Jamalludin, 2018).

Faktor benih, pupuk kandang dan tenaga kerja memiliki pengaruh yang positif dan nyata terhadap besarnya hasil produksi sayuran yang dibudidayakan (Kalauw et al., 2015). Faktor produksi tenaga kerja berpengaruh positif dan signifikan terhadap peningkatan produksi tanaman (Annisa et al., 2019). Hasil produksi kelompok tani Tranggulasi tidak hanya dijual di pasar lokal tetapi sudah menembus pasar ekspor. Jumlah permintaan konsumen yang cenderung tinggi tetapi produktivitas sayuran yang rendah, dapat mempengaruhi tingkat penjualan dan profit yang akan diterima oleh kelompok tani.

Hasil produksi kelompok tani Tranggulasi tidak hanya dijual di pasar lokal tetapi sudah menembus pasar ekspor. Permintaan pasar terhadap komoditas buncis perancis sebanyak 1,5-3 ton per hari, akan tetapi volume produksi buncis perancis kelompok tani Tranggulasi hanya 1,5-3 ton per minggu. Kelompok tani Tranggulasi tidak mampu memenuhi permintaan pasar yang cenderung tinggi tetapi produktivitas sayuran yang rendah. Hal ini menjadi sebuah hambatan bagi kelompok tani Tranggulasi untuk mencapai pemenuhan kebutuhan pasar dan keberlangsungan usaha tani.
Berdasarkan uraian diatas, karena produksi komoditas buncis perancis pada kelompok tani Tranggulasi tidak dapat memenuhi permintaan maka dilakukan penelitian untuk menganalisis faktor-faktor yang mempengaruhi produktivitas buncis perancis. Dengan demikian tujuan penelitian ini adalah Menganalisis faktorfaktor yang berpengaruh terhadap produktivitas buncis perancis di kelompok tani Tranggulasi, Desa Batur, Kecamatan Getasan, Kabupaten Semarang.

\section{METODE PENELITIAN}

Lokasi penelitian ini berada di Desa Batur, Kecamatan Getasan, Kabupaten Semarang pada kelompok tani Tranggulasi. Pemilihan tempat penelitian dilakukan secara sengaja dengan mempertimbangkan kelompok tani Tranggulasi melakukan usahatani dengan menggunakan faktor produksi organik serta sebagai sentra penghasil sayuran organik dengan permintaan yang tinggi. Penelitian dilaksanakan pada bulan Agustus 2020. Jenis penelitian yang digunakan adalah penelitian deskriptif kuantitatif. Teknik pengambilan sampel yang digunakan adalah teknik purposive sampling yaitu mengambil sampel berdasarkan pertimbangan dengan memperhatikan kriteria tertentu. Adapun kriteria sampel dalam penelitian ini adalah kelompok tani yang melakukan usahataninya dengan 
sistem pertanian organik. Dengan jumlah sampel sebanyak 30 anggota kelompok tani Tranggulasi. Pada saat ukuran sampel mencapai $\mathrm{n}=30$ telah memiliki bentuk normal (Morissan, 2016). Data yang diperoleh dianalisis dengan pemodelan fungsi produksi regresi berganda dengan bantuan program SPSS 16.

Jenis data yang digunakan dalam penelitian ini adalah data primer dan data sekunder. Data primer merupakan data yang diperoleh secara langsung dari sampel penelitian yaitu petani. Sedangkan data Tabel 1. Karakteristik petani responden

\begin{tabular}{|c|c|c|c|c|}
\hline $\mathrm{No}$ & Karakteristik & Kategori & Jumlah responden & Persentase (\%) \\
\hline \multirow[t]{7}{*}{1} & Umur (Tahun) & $35-41$ & 5 & 17 \\
\hline & & $42-48$ & 9 & 30 \\
\hline & & $49-55$ & 8 & 27 \\
\hline & & $56-62$ & 4 & 13 \\
\hline & & $63-69$ & 2 & 7 \\
\hline & & $70-76$ & 2 & 7 \\
\hline & & Total & 30 & 100 \\
\hline \multirow[t]{3}{*}{2} & Jenis Kelamin & Laki-laki & 28 & 93 \\
\hline & & Perempuan & 2 & 7 \\
\hline & & Total & 30 & 100 \\
\hline \multirow[t]{5}{*}{3} & Pendidikan & SD sederajat & 17 & 57 \\
\hline & & SMP sederajat & 4 & 13 \\
\hline & & SMA/SMK & 5 & 17 \\
\hline & & S1 sederajat & 4 & 13 \\
\hline & & Total & 30 & 100 \\
\hline \multirow[t]{3}{*}{4} & Luas lahan & 0,1 ha & 28 & 93 \\
\hline & & 0,2 ha & 2 & 7 \\
\hline & & Total & 30 & 100 \\
\hline \multirow[t]{5}{*}{5} & Peran & Ketua & 1 & 3 \\
\hline & & Sekretaris & 1 & 3 \\
\hline & & Bendahara & 1 & 3 \\
\hline & & Anggota & 27 & 90 \\
\hline & & Total & 30 & 100 \\
\hline
\end{tabular}

Sumber: Data primer diolah, 2020. sekunder merupakan data yang diperoleh dari pihak lain seperti Badan Pusat Statistik (BPS), jurnal, dan media cetak maupun elektronik melalui studi pustaka. Teknik pengumpulan data pada penelitian ini adalah obsevasi, wawancara dan studi pustaka. Teknik analisis data penelitian yaitu dengan uji normalitas, uji multikolinearitas, uji heteroskedastisitas, uji autokorelasi. Analisis data berdasarkan tujuan 1 dan 2 adalah dengan analisis regresi linier berganda. 


\section{HASIL DAN PEMBAHASAN}

\section{Karakteristik Petani Responden}

Adapun katakteristik petani responden pada penelitian ini adalah berdasarkan umur, jenis kelamin, pendidikan, luas lahan yang digarap untuk menanam buncis perancis dan peran petani dalam kelompok tani.

Berdasarkan Tabel 1 dapat diketahui bahwa petani responden dengan umur $42-$ 48 tahun merupakan tingkat umur dengan jumlah terbanyak yaitu 9 orang atau $30 \%$ maka termasuk dalam golongan yang produktif dan jumlah petani yang paling sedikit adalah tingkat usia 63-69 dan usia 70-76 tahun setiap tingkat sebanyak 2 orang atau $7 \%$. Bahkan sebagian besar petani yang mengelola usahatani adalah laki-laki sebanyak 28 orang atau $93 \%$ dan petani perempuan hanya 2 orang atau $7 \%$, sehingga dengan kondisi produktif ini petani diharapkan mampu memberikan kontribusi yang lebih besar terhadap usahataninya.

Dari Tabel 1 menunjukkan bahwa tingkat pendidikan yang dimiliki oleh petani responden terdiri dari empat tingkat pendidikan yaitu SD sederajat, SMP sederajat, SMA sederajat dan Strata 1 (S1). Nilai persentase tertinggi untuk tingkat pendidikan pada kelompok tani Tranggulasi yaitu pada tingkat SD sederajat dengan jumlah responden sebanyak 17 orang atau $57 \%$. Sedangkan untuk tingkat pendidikan
SMP sederajat $13 \%$ atau 4 orang, tingkat pendidikan SMA/SMK sederajat sebanyak 5 orang atau $17 \%$ dan tingkat S1 sebanyak $13 \%$ atau 4 orang.

Berdasarkan Tabel 1 dapat diketahui luas lahan tanaman Buncis Perancis yang dibudidayakan oleh kelompok tani Tranggulasi dengan masing-masing petani memiliki luas lahan 0,1-02 ha. Adapun rinciannya adalah sebanyak 28 petani atau $93 \%$ memiliki luas lahan 0,1 ha dan sebanyak 2 petani atau $7 \%$ memiliki luas lahan 0,2 ha.

Berdasarkan Tabel 1 dapat diketahui bahwa peran petani responden dalam kelompok tani Tranggulasi terdiri dari ketua kelompok 1 orang atau $3 \%$, sekretaris 1 orang atau $3 \%$, bendahara 1 orang atau 3 $\%$, dan sebanyak 27 orang atau $90 \%$ berperan sebagai anggota dalam kelompok tersebut.

\section{Uji Normalitas}

Hasil uji normalitas usahatani buncis perancis di Kelompok Tani Tranggulasi sebagai responden penelitian dapat dilihat dari Tabel 2. Uji normalitas merupakan salah satu uji asumsi klasik yang bertujuan untuk mengetahui data sampel yang digunakan terdistribusi secara normal atau tidak. Pengujian normalitas pada penelitian ini adalah dengan uji Kolmogorov Smirnov melalui SPSS 16. Disamping itu, jika nilai signifikansinya $<0,05$ berarti terdapat 
Tabel 2. Hasil uji normalitas

\begin{tabular}{cc}
\hline Keterangan & Unstandardized Residual \\
\hline $\mathrm{N}$ & 30 \\
Kolmogorov-Smirnov Z & 1,028 \\
\hline Asymp. Sig. (2-tailed) & 0,242 \\
\hline
\end{tabular}

Sumber: Data primer diolah, 2020.

Tabel 3. Hasil uji multikolinearitas

\begin{tabular}{lcc}
\hline \multicolumn{1}{c}{ Variabel } & Tolerance & VIF \\
\hline Luas lahan (ha) & 0,181 & 5,532 \\
Benih (kg/ha) & 0,288 & 3,467 \\
Pupuk Organik (kg/ha) & 0,425 & 2,351 \\
Tenaga kerja (HOK/ha) & 0,776 & 1,288 \\
Pestisida Organik (L/ha) & 0,441 & 2,270 \\
\hline
\end{tabular}

Sumber: Data primer diolah, 2020.

perbedaan yang signifikan (data yang diuji tidak normal) sedangkan jika nilai signifikansinya $>0,05$ berarti tidak terjadi perbedaan yang signifikan.Berdasarkan Tabel 2, diketahui bahwa nilai asymp. sig. (2-tailed) sebesar 0,242 adalah lebih besar dari 0,05 (asymp. sig. (2-tailed) > 0,05). Maka dapat disimpulkan bahwa data yang digunakan dalam penelitian ini berdistribusi normal.

\section{Uji Multikolinearitas}

Dalam penelitian ini dilakukan uji multikolinearitas yang bertujuan untuk mengetahui apakah setiap variabel bebas memiliki hubungan linear atau tidak. Untuk mengetahui masalah multikolinearitas yaitu dengan melihat nilai VIF (Variance Inflation Factor), jika nilai toleransi > 0,10 dan nilai VIF < 10 maka data yang digunakan tidak mengalami penyimpangan multikolinearitas.
Berdasarkan Tabel 3, diketahui bahwa masing-masing variabel independen memiliki nilai tolerance $>0,10$ dan nilai $\mathrm{VIF}<10$. Artinya bahwa variabel yang digunakan dalam penelitian ini tidak mengalami masalah multikolinearitas

\section{Uji Heteroskedastisitas}

Uji heteroskedastisitas dilakukan dalam penelitian ini untuk mengetahui varian variabel dalam model yang diamati tidak sama. Untuk menguji ada tidaknya heteroskedastisitas dalam model regresi adalah dengan uji Glejser dengan melihat nilai signifikansinya.

$$
\text { Berdasarkan hasil uji }
$$
heteroskedastisitas diatas dapat diketahui bahwa nilai signifikansi setiap variabel independen yaitu luas lahan, benih, pupuk organik, tenaga kerja dan pestisida organik lebih besar dari 0,05. Artinya bahwa data 
yang digunakan dalam penelitian tidak mengandung masalah heteroskedastisitas.

Berdasarkan hasil uji heteroskedastisitas diatas dapat diketahui bahwa nilai signifikansi setiap variabel independen yaitu luas lahan, benih, pupuk organik, tenaga kerja dan pestisida organik lebih besar dari 0,05. Artinya bahwa data yang digunakan dalam penelitian tidak mengandung masalah heteroskedastisitas.

\section{Uji Autokorelasi}

Berdasarkan Tabel 5 dapat diketahui bahwa nilai tabel yang digunakan dalam pada penelitian ini yaitu menggunakan nilai signifikansi 0,05 dengan jumlah sampel (n) sebesar 30 orang dan jumlah variabel independennya sebanyak 5 variabel. Dapat simpulkan bahwa nilai Durbin Watson (DW) terletak diantara $4-\mathrm{du}<\mathrm{DW}<4-$ dl. Dimana nilai du sebesar 1,833, dan dl sebesar 1,070 serta nilai DW sebesar 2,202.

Tabel 4. Hasil uji heteroskedastisitas

\begin{tabular}{lrr}
\hline \multicolumn{1}{c}{ Variabel } & T & Sig. \\
\hline Luas lahan (ha) & $-1,904$ & 0,069 \\
Benih (kg/ha) & 1,279 & 0,213 \\
Pupuk Organik (kg/ha) & $-0,722$ & 0,477 \\
Tenaga kerja (HOK/ha) & $-1,306$ & 0,204 \\
Pestisida Organik (Liter/ha) & $-0,165$ & 0,870 \\
\hline
\end{tabular}

Sumber: Data primer diolah, 2020.

Tabel 5. Hasil uji autokorelasi

\begin{tabular}{cccccc}
\hline Model & $\mathrm{R}$ & $\mathrm{R}$ Square & Adjusted R square & $\begin{array}{c}\text { Std. Error of the } \\
\text { estimate }\end{array}$ & Durbin-Watson \\
\hline 1 & $0,680^{\mathrm{a}}$ & 0,462 & 0,350 & 0,04958 & 2,202 \\
\hline
\end{tabular}

Sumber: Data primer diolah, 2020. 
Tabel 6. Hasil uji koefisien determinasi $\left(\mathrm{R}^{2}\right)$

\begin{tabular}{ccc}
\hline Model & R-Adjustment & R Square \\
\hline 1 & $0,680^{\mathrm{a}}$ & 0,462 \\
\hline
\end{tabular}

Sumber: Data primer diolah, 2020.

Tabel 7. Hasil uji F (Simultan)

\begin{tabular}{ccc}
\hline Variabel & F & Sig. \\
\hline Variabel Independen & 4,124 & $0,008^{\mathrm{a}}$ \\
\hline
\end{tabular}

Sumber: Data primer diolah, 2020.

Tabel 8. Hasil Uji t (Parsial)

\begin{tabular}{lcc}
\hline \multicolumn{1}{c}{ Variabel } & $\mathrm{t}$ & Sig. \\
\hline $\mathrm{X}_{1}($ Luas lahan (ha)) & $-1,138$ & 0,266 \\
$\mathrm{X}_{2}$ (Benih (kg/ha)) & 1,595 & 0,124 \\
$\mathrm{X}_{3}$ (Pupuk Organik (kg/ha)) & 2,625 & 0,015 \\
$\mathrm{X}_{4}$ (Tenaga kerja (HOK/ha)) & 0,860 & 0,398 \\
$\mathrm{X}_{5}$ (Pestisida Organik (Liter/ha)) & 0,217 & 0,830 \\
\hline
\end{tabular}

Sumber: Data primer diolah, 2020.

\section{Uji F (Simultan)}

Uji F merupakan salah satu dari regresi linier berganda yang berfungsi untuk mengetahui seberapa besar pengaruh secara bersama-sama variabel bebas yaitu luas lahan $\left(\mathrm{X}_{1}\right)$, benih $\left(\mathrm{X}_{2}\right)$, pupuk organik $\left(\mathrm{X}_{3}\right)$, tenaga kerja $\left(\mathrm{X}_{4}\right)$ dan pestisida organik $\left(\mathrm{X}_{5}\right)$ terhadap variabel terikat yaitu produktivitas buncis perancis (Y). Dasar pengambilan keputusan dalam uji ini adalah bila f hitung > f tabel maka dapat dikatakan bahwa secara serempak semua variabel bebas berpengaruh nyata terhadap variabel terikat.

Berdasarkan Tabel 7 didapatkan bahwa nilai $\mathrm{F}$ hitung sebesar 4,124 dan diperoleh nilai $F$ tabel sebesar 2,752. Hal ini menunjukan bahwa nilai F hitung $(4,124)>$ F tabel $(2,752)$ artinya secara bersama- sama variabel bebas mempengaruhi variabel terikat. Hasil uji F yang dilakukan dalam penelitian ini dapat dilihat di Tabel 7.

\section{Uji t (Parsial)}

Tabel 8 merupakan tabel hasil uji $\mathrm{t}$ (parsial) pada semua input produksi (X) yang digunakan sebagai variabel bebas terhadap produktivitas buncis perancis $(\mathrm{Y})$. Uji t (parsial) dilakukan untuk mengetahui pengaruh masing-masing variabel $X$ terhadap variabel $Y$. Adapun kriteria pengambilan keputusannya yaitu nilai signifikansinya harus $\leq 0,05$ sehingga dapat dikatkan bahwa variabel $\mathrm{X}$ memiliki pengaruh nyata terhadap variabel $\mathrm{Y}$. Berdasarkan Tabel 8 diketahui bahwa variabel bebas yang berpengaruh nyata terhadap variabel $\mathrm{Y}$ (produktivitas buncis perancis) adalah variabel $\mathrm{X}_{3}$ (pupuk 
p-ISSN: 1410-0029; e-ISSN2549-6786

Agrin Vol. 25, No. 1, April 2021

Tabe1 9. Hasil analisis faktor-faktor yang mempengaruhi produktivitas buncis

\begin{tabular}{|c|c|c|c|c|c|c|}
\hline \multirow{2}{*}{ Variabel } & \multicolumn{2}{|c|}{$\begin{array}{c}\text { Unstandardized } \\
\text { Coefficients }\end{array}$} & $\begin{array}{c}\text { Standardized } \\
\text { Coefficients }\end{array}$ & \multirow{2}{*}{$\mathrm{t}$} & \multirow{2}{*}{ Sig. } & \multirow{2}{*}{ Keterangan } \\
\hline & B & $\begin{array}{l}\text { Galat } \\
\text { Standar }\end{array}$ & Beta & & & \\
\hline (Constant) & 0,141 & 0,156 & & 0,906 & 0,374 & \\
\hline Luas lahan (ha) & $-0,808$ & 0,710 & $-0,401$ & $-1,138$ & 0,266 & $\begin{array}{l}\text { Memiliki hubungan } \\
\text { negatif dan tidak } \\
\text { signifikan }\end{array}$ \\
\hline Benih (kg/ha) & 0,054 & 0,034 & 0,445 & 1,595 & 0,124 & $\begin{array}{l}\text { Memiliki hubungan } \\
\text { positif dan tidak } \\
\text { signifikan }\end{array}$ \\
\hline $\begin{array}{l}\text { Pupuk Organik } \\
\text { (kg/ha) }\end{array}$ & 0,116 & 0,044 & 0,603 & 2,625 & 0,015 & $\begin{array}{l}\text { Memiliki hubungan } \\
\text { positif dan signifikan }\end{array}$ \\
\hline $\begin{array}{l}\text { Tenaga kerja } \\
(\text { HOK/ha) }\end{array}$ & 0,026 & 0,030 & 0,146 & 0,860 & 0,398 & $\begin{array}{l}\text { Memiliki hubungan } \\
\text { positif dan tidak } \\
\text { signifikan }\end{array}$ \\
\hline $\begin{array}{l}\text { Pestisida Organik } \\
\text { (L/ha) }\end{array}$ & 0,022 & 0,099 & 0,049 & 0,217 & 0,830 & $\begin{array}{l}\text { Memiliki hubungan } \\
\text { positif dan tidak } \\
\text { signifikan }\end{array}$ \\
\hline
\end{tabular}

Sumber: Data primer diolah, 2020.

organik) dengan nilai $0,015<0,05$, sehingga variabel terikat lainya secara parsial tidak berpengaruh nyata terhadap produktivitas buncis perancis $(\mathrm{Y})$.

\section{Hasil Analisis Faktor-Faktor yang Mempengaruhi Produktivitas Buncis Perancis}

Tabel 9 merupakan hasil analisis data input produksi $(\mathrm{X})$ terhadap produktivitas buncis perancis ( $\mathrm{Y}$ ) pada kelompok Tani Tranggulasi Desa Batur. Hasil analisis regresi linier diperoleh model persamaan untuk usahatani buncis perancis adalah $\mathrm{Y}=$ $0,141+\left(-0,808 \mathrm{X}_{1}\right)+0,054 \mathrm{X}_{2}+0,116 \mathrm{X}_{3}+$ $0,026 \mathrm{X}_{4}+0,022 \mathrm{X}_{5}$.

Hasil analisis yang telah dilakukan diketahui bahwa tidak semua variabel bebas yaitu faktor produksi mempengaruhi produktivitas buncis perancis. Berdasarkan hasil persamaan regresi tersebut dapat dijelaskan sebagai berikut:

1) Koefisien constant (a) sebesar 0,141 menunjukkan bahwa jika nilai $\mathrm{X}$ sama dengan nol (0) atau tidak ada input maka nilai Y akan mengalami kenaikan sebesar 0,141 satuan.

2) Koefisien $X_{1}$ (Luas lahan) sebesar 0,808 dimana pada saat nilai $\mathrm{X}_{1}$ (Luas lahan) mengalami kenaikan 1 ha, maka produktivitas buncis perancis yang dibudidayakan akan mengalami penurunan sebesar 0,808 .

3) Koefisien $X_{2}$ (Benih) dengan nilai sebesar 0,054 dimana apabila $\mathrm{X}_{2}$ (Benih) mengalami kenaikan $1 \mathrm{~kg} / \mathrm{ha}$ 
maka produktivitas buncis perancis mengalami kenaikan $0,054 \mathrm{~kg} / \mathrm{ha}$.

4) Koefisien $X_{3}$ (Pupuk Organik) dengan nilai sebesar 0,116 dimana pada saat $\mathrm{X}_{3}$ (Pupuk Organik) mengalami kenaikan 1 $\mathrm{kg} / \mathrm{ha}$ maka produktivitas buncis perancis mengalami kenaikan 0,116 $\mathrm{kg} / \mathrm{ha}$.

5) Koefisien $X_{4}$ (Tenaga Kerja) sebesar 0,026 dimana pada saat $\mathrm{X}_{4}$ (Tenaga Kerja) mengalami kenaikan $1 \mathrm{HOK} / \mathrm{ha}$ maka produktivitas buncis akan naik sebesar 0,026.

6) Koefisien $X_{5}$ (Pestisida Organik) sebesar 0,022 dimana pada saat $\mathrm{X}_{5}$ (Pestisida Organik) mengalami kenaikan 1 liter/ha maka produktivitas buncis akan naik sebesar 0,022 .

\section{Pembahasan}

\section{Pengaruh Luas Lahan terhadap Produktivitas Buncis Perancis pada Kelompok Tani Tranggulasi}

Sesuai dengan hasil analisis faktorfaktor produktivitas buncis perancis pada kelompok tani Tranggulasi diperoleh variabel luas lahan $\left(\mathrm{X}_{1}\right)$ dengan nilai koefisien adalah $-0,808$ dengan nilai $\mathrm{t}$ hitung sebesar -1,138 lebih kecil daripada nilai $t_{\text {tabel }}$ sebesar 1,708 dan nilai p-value sebesar 0,266 lebih besar dari tingkat signifikansi 0,05 maka variabel luas lahan tidak berpengaruh nyata dan memiliki hubungan negatif terhadap produktivitas buncis perancis. Dengan demikian dapat disimpulkan bahwa $\mathrm{H} 0$ diterima dan $\mathrm{H} 1$ ditolak artinya tidak terdapat pengaruh luas lahan terhadap produktivitas buncis perancis.

Hal ini terjadi karena pemanfaatan lahan budidaya buncis perancis pada kelompok tani Tranggulasi belum optimal dapat dilihat dari lahan yang dimiliki tidak diolah sebaik mungkin. Padahal masingmasing petani memiliki luas lahan sekitar 0,3-0,7 ha untuk menanam tanaman kacang-kacangan dan umbi-umbian. Namun demikian, lahan yang digunakan untuk budidaya buncis perancis hanya $0,1-$ 0,2 ha. Disamping itu masing-masing petani perlu mengolah lahan yang sudah ditentukan dengan baik. Karena jika dilakukan penambahan luas lahan khususnya untuk meningkatkan produktivitas buncis perancis akan mengeluarkan modal. Oleh karena itu upaya yang dilakukan adalah dengan mengatur pola tanam yang sesuai untuk tanaman buncis perancis.

Hasil ini sejalan dengan hasil penelitian. Deviani et al. (2019), menjelaskan bahwa luas lahan tidak berpengaruh nyata terhadap produksi buncis, dan apabila dilakukan penambahan luas lahan untuk meningkatkan produksi maka modal yang dikeluarkan petani untuk memproduksi buncis semakin bertambah. Hasil penelitian ini tidak sejalan dengan 
hasil penelitian Lama \& Kune (2016), menyatakan bahwa variabel luas lahan secara parsial berpengaruh sangat nyata terhadap produktivitas sayur sawi.

\section{Pengaruh Benih terhadap Produktivitas Buncis Perancis pada Kelompok Tani Tranggulasi}

Berdasarkan Tabel 9 diketahui bahwa variabel benih $\left(\mathrm{X}_{2}\right)$ memiliki hubungan yang positif tetapi tidak berpengaruh nyata terhadap produktivitas buncis perancis.

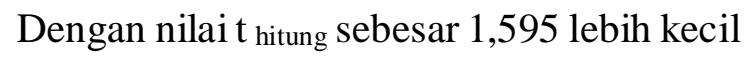
daripada nilai $t_{\text {tabel }}$ sebesar 1,708 dan nilai $p$ value sebesar 0,124 lebih besar dari tingkat signifikansi 0,05. Berdasarkan hasil uji statistik ini dapat disimpulkan bahwa $\mathrm{HO}$ diterima dan H1 ditolak artinya tidak terdapat pengaruh benih terhadap produktivitas buncis perancis.

Tidak signifikannya variabel benih terhadap produktivitas buncis perancis kemungkinan terjadi karena benih yang digunakan oleh kelompok tani Tranggulasi merupakan benih yang diproduksi sendiri. Apabila dalam proses produksi benih mengalami kesalahan maka dapat menimbulkan masalah genetik pada benih itu sendiri serta mempengaruhi kualitasnya. Penelitian yang dilakukan ini selaras dengan hasil penelitian lain meskipun komoditas berbeda, Yusuf et al. (2014) menyatakan bahwa variabel benih tidak berpengaruh secara signifikan terhadap produksi jagung.

\section{Pengaruh Pupuk Organik terhadap Produktivitas Buncis Perancis pada Kelompok Tani Tranggulasi}

Pengaruh pupuk organik $\left(\mathrm{X}_{3}\right)$ terhadap produktivitas buncis perancis $(\mathrm{Y})$ adalah signifikan dan memiliki hubungan yang positif. Dapat dilihat pada Tabel 9 yang menunjukan bahwa nilai $t_{\text {hitung sebesar }}$ 2,625 lebih besar daripada nilai $t_{\text {tabel }}$ sebesar 1,708 dan p-value 0,015 lebih kecil dari tingkat signifikansinya yaitu 0,05 . Ber dasarkan uji statistik tersebut dapat disimpulkan bahwa pupuk organik berpengaruh nyata terhadap produktivitas buncis perancis dimana $\mathrm{H} 0$ ditolak dan $\mathrm{H} 1$ diterima artinya terdapat pengaruh pupuk organik terhadap produktivitas buncis.

Pupuk organik yang digunakan oleh kelompok tani Tranggulasi merupakan pupuk yang berasal dari kotoran ternak sapi, jenis pupuk organik ini disebut pupuk kandang. Pupuk organik tersebut diproduksi sendiri oleh kelompok tani Tranggulasi sehingga anggota kelompok tani dapat menekan biaya yang dikeluarkan dalam usaha tani yang dijalankan. Serta memiliki kelebihan yaitu memperbaiki struktur tanah, menaikkan daya serap tanah terhadap air, menaikkan kondisi kehidupan di dalam tanah dan sebagai sumber zat makanan tanaman.

Dengan demikian, penggunaan pupuk organik pada kelompok tani Tranggulasi dapat dipertahankan dan ditingkatkan 
supaya dapat meningkatkan produktivitas buncis perancis. Hasil penelitian yang selaras dihasilkan oleh Fefiani \& Barus (2014) yang menyebutkan bahwa pemberian pupuk kandang sapi sangat berpengaruh nyata terhadap panjang tanaman, panjang buah dan berat buah sehingga produktivitas tanaman akan mengalami peningkatan.

\section{Pengaruh Tenaga Kerja terhadap Produktivitas Buncis Perancis pada Kelompok Tani Tranggulasi}

Berdasarkan hasil uji statistik

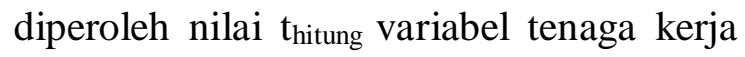
$\left(\mathrm{X}_{4}\right)$ sebesar 0,860 lebih kecil dari nilai $\mathrm{t}_{\text {tabel }}$ sebesar 1,708 dengan nilai p-value 0,398 lebih besar dari tingkat signifikansi 0,05. Artinya bahwa variabel tenaga kerja $\left(\mathrm{X}_{4}\right)$ tidak berpengaruh nyata terhadap produktivitas buncis perancis, walaupun arah hubungannya positif. Oleh karena dapat disimpulkan bahwa $\mathrm{HO}$ diterima dan H1 ditolak artinya tidak terdapat pengaruh tenaga kerja terhadap produktivitas buncis.

Hal ini kemungkinan terjadi karena petani yang tergabung dalam kelompok tani Tranggulasi banyak menggunakan tenaga kerja keluarga dalam usahatani yang dijalankan. Penggunaan tenaga kerja keluarga membuat petani tidak begitu memperhatikan pemberdayaan tenaga kerja dalam mengerjakan lahannya. Oleh karena itu jumlah tenaga kerja dalam usahatani buncis perancis dan pemberdayaan tenaga kerja perlu ditingkatkan. Hartati \& Setyadji (2012), menjelaskan bahwa secara simultan faktor produksi tenaga kerja berpengaruh sangat nyata terhadap tanaman kentang tetapi secara parsial tidak berpengaruh nyata.

\section{Pengaruh Pestisida Organik terhadap Produktivitas Buncis Perancis pada Kelompok Tani Tranggulasi}

Berdasarkan Tabel 8 menunjukkan bahwa nilai thitung variabel pestisida organik $\left(X_{5}\right)$ sebesar 0,217 lebih kecil dari nilai $t_{\text {tabel }}$ sebesar 1,708 dengan nilai $p$-value 0,830 lebih besar dari taraf signifikansi 0,05. Hasil uji tersebut dapat disimpulkan bahwa variabel pestisida organik tidak berpengaruh nyata terhadap produktivitas buncis perancis akan tetapi memiliki arah hubungan yang positif. Hipotesis $\mathrm{HO}$ diterima dan $\mathrm{H} 1$ ditolak artinya tidak terdapat pengaruh pestisida organik terhadap produktivitas buncis.

Tidak berpengaruhnya variabel pestisida organik terhadap produktivitas buncis perancis diduga disebabkan oleh pestisida yang digunakan diproduksi sendiri sehingga keefektifan belum teruji secara maksimal. Dengan demikian perlu dilakukan pengujian untuk meningkatkan kemampuan pestisida organik dalam mengendalikan hama atau penyakit pada tanaman buncis perancis. Hasil ini diperkuat dengan hasil penelitian Kalauw et al. (2015), menyebutkan bahwa variabel 
pestisida bernilai positif dan tidak berpengaruh nyata terhadap produksi buncis, dengan demikian petani harus memperhatikan kandungan dan keefektifan pestisida yang digunakan dalam usahatani.

\section{KESIMPULAN}

Sistem budidaya buncis perancis pada Kelompok Tani Tranggulasi Semarang menunjukan bahwa faktor produksi antara lain luas lahan, benih, pupuk organik, tenaga kerja dan pestisida organik mempengaruhi produktivitas serta faktor produksi yang paling mempengaruhi dalam peningkatan produktivitas secara parsial adalah pupuk organik.

\section{DAFTAR PUSTAKA}

Annisa, R., Siswandi, B., \& Syakir, F. (2019). Faktor-faktor sosial ekonomi yang mempengaruhi risiko produksi usahatani jagung (Zea mays Sp.) Di Desa Wonorejo Kecamatan Sumbergempol Kabupaten Tulungagung. Jurnal Sosial Ekonomi Pertanian dan Agribisnis, 7(1), 1-11.

Deviani, F., Rochdiani, D., \& Saefudin, B. R. (2019). Analisis faktor-faktor yang mempengaruhi produksi usahatani buncis Di Gabungan Kelompok Tani Lembang Agri Kabupaten Bandung Barat. Agrisocionomics:Jurnal Sosial Ekonomi Pertanian, 3(2), 165-173. https://doi.org/10.14710/agrisociono mics.v3i2.6099.

Eka, A. V., \& Gilang, C. I. (2013). Karakterisasi Enam varietas buncis (Phaseolus vulgaris L.) berdasarkan panduan pengujian individual. Jurnal Agric, 25(1), 34-41.
Fefiani, Y., \& Barus, W. A. (2014). Respon pertumbuhan dan produksi tanaman mentimun (Cucumis sativus L.) akibat pemberian pupuk kandang sapi dan pupuk organik padat supernasa. Agrium: Jurnal Ilmu Pertanian, 19(1), 21-30. http://jurnal.umsu.ac.id /index.php/agrium/article/view/328.

Hartati, A., \& Setyadji, K. (2012). Tingkat efisiensi faktor produksi pada usahatani kentang di Kecamatan Karangreja Kabupaten Purbalingga Jawa Tengah. Agrin, 16(1), 1-30.

Jamalludin, J. (2018). Analisis faktor-faktor yang mempengaruhi produksi usahatani sayur-sayuran di Kelurahan Maharatu Kecamatan Marpoyan Damai Kota Pekanbaru. Jurnal Agribisnis, 20(1), 52-67. https:// doi.org/10.31849/agr.v20i1.1496

Kalauw, S. H. S., Timisela, N. R., \& Tuhumury, M. T. F. (2015). Analisis faktor-faktor yang mempengaruhi produksi sayuran buncis (phaseolus vulgaris L.) di Dusun Telaga Kodok Kabupaten Maluku Tengah. Agrilan, 3(2), 140-156.

Lama, M., \& Kune, S. J. (2016). Faktorfaktor yang mempengaruhi produksi usaha tani sayur sawi di Kelurahan Bensone Kecamatan Kota Kefamenanu Kabupaten Timor Tengah Utara. Agrimor, 1(2), 27-29. https://doi.org/10.32938/ag.v1i02.10 2

Martono, R.V. (2019). Analisis Produktivitas dan Efisiensi. PT.Gramedia Pustaka Utama.

Morissan. (2016). Statistik Sosial (Pertama). Kencana.

Yusuf, H., Hasnudi, \& Lubis, Y. (2014). Analisis faktor-faktor yang mempengaruhi produksi jagung di Kabupaten Aceh Tenggara. Jurnal Agrica, 7(2), 65-73. 
p-ISSN: 1410-0029; e-ISSN2549-6786

Agrin Vol. 25, No. 1, April 2021 